\title{
Experimental mapping and assessment of ecosystem services based on multi-level landscape classification
}

\author{
Hristina Prodanova * (D) \\ National Institute of Geophysics, Geodesy and Geography - Bulgarian Academy of Sciences, Sofia, Bulgaria \\ ${ }^{\star}$ Corresponding author: hristina.zh.prodanova@gmail.com
}

\begin{tabular}{|c|c|}
\hline & ABSTRACT \\
\hline $\begin{array}{l}\text { Key words: } \\
\text { capacity scores, matrix, natural heri- } \\
\text { tage, cultural ecosystem services, } \\
\text { expert-based assessment }\end{array}$ & $\begin{array}{l}\text { The importance of the landscapes for the development of recreation and ecotourism is significant } \\
\text { but very little studied. Usually, scientists use spatial units to map and assess the ecosystem services } \\
\text { CORINE land cover or similar classifications. Traditional multi-level landscape classifications, } \\
\text { very well-known and developed in the XX }{ }^{\text {th }} \text { century in Bulgaria, Russia, and other Eastern and }\end{array}$ \\
\hline & $\begin{array}{l}\text { Central European countries, could give valuable information for various indicators for ecosystem } \\
\text { services assessment. From another hand, these classical landscape ecological maps are very little- } \\
\text { known for the international scientific audience. We decided to conduct an experimental mapping } \\
\text { and assessment of ecosystem services based on multi-level landscape classification. For this, } \\
\text { we have chosen a case study area with hilly karst relief, which is part of the inner Predbalkan } \\
\text { Region, located in North-Central Bulgaria. The site represents a scientific interest in terms of } \\
\text { its transitional position between the Stara Planina Mountain and the Danube Plain and the } \\
\text { presence of various anthropogenic changes. The study aimed to develop and test an original } \\
\text { methodology for mapping and assessment of the capacity of the contemporary landscapes in the } \\
\text { Strazhata syncline upland and Melovete hills to provide cultural ecosystem services - recreation } \\
\text { and ecotourism. The results showed that } 70 \% \text { of the territory has medium or higher capacity, } \\
\text { dominated mainly by karst areas with natural vegetation in protected sites. }\end{array}$ \\
\hline
\end{tabular}

Article processing

Submitted: 30 September 2021

Accepted: 23 December 2021

Published: 29 December 2021

Academic editor: Bilyana Borisova

(C) H. Prodanova. This is an open access article distributed under the terms of the Creative Commons Attribution License (CC BY 4.0), which permits unrestricted use, distribution, and reproduction in any medium, provided the original author and source are credited.

\section{Introduction}

Scientists from different countries have different perceptions of the landscape, its definitions, mapping and classification system accordingly. Hugget and Perkins (2004) argue that core concepts of 'landscape' stem from European sources. Most Germanic languages used the word 'landscape' ("landschaft" in German; "lantschap" in Dutch) in the early Middle Ages as a counterpart for the Latin words - "regio", "patria", or "provincia", meaning area, territory, or region. In German-speaking countries, academics dealing with landscape science are S Passarge, C Troll, L Finke, G Haase, E Neef and others (Konteva 2004). In the early XX ${ }^{\text {th }}$ century, Passarge (1921) developed the idea of natural landscapes, and later H Ellenberg, Finke (1996) and others proposed definitions of landscape (Neef 1961, Neef et al. 1967, Richter 1961, Richter 1967, Haase et al. 1991, Potchin 1996, Haase and Mannsfeld 2002). In the Russian landscape studies, VV Dokuchaev (1898) and LS Berg (1913), considered to be the founders of landscape science, followed by AA Grigoriev, B Polinov, NA Solntsev 1948, AG Isachenko 1961, 1962a, 1962b, 1963, and others. Like Passarge, Berg (1938) views the geographical landscape as a set of objects and phenomena. Set in which the features of relief, climate, water, soil, flora and fauna and, to some extent - human activity, merge into one, typical and recurring in a given area on the Earth. According to Zhelezov and Nedkov (2019), and Tzvetkov (2021) the first landscape studies in Bulgaria have been applied by Radev (1921), Yaranov (1933), Batakliev (1934) and Penkov (1943). 
There are various classification systems in landscape science in which landscapes are grouped, according to particular approaches and principles applied in the study. Bulgarian scientists adopted the classifications of NA Gvozdetsky, AG Isachenko, VA Nikolaev and LN Beruchashvili and further developed them into regional studies. As Tzvetkov (2021) explains, landscape maps in the Eastern European studies are the standard basis for characterising the horizontal landscape structure, and the map's legend reflects the landscape classification.

Nowadays, the importance of landscape studies in Bulgaria is more or less shading due to the reorientation of researchers to other study areas. The number of scientists and studies in the last ten years is decreasing, and only a few people are exploring landscapes in their classical dimensions (Konteva et al. 2008), i.e. regarding theoretical aspects (Stoyanova 2016, Zhelezov and Nedkov 2019, Petrova 2020, Tzvetkov 2021), geophysical processes (Todorov and Alexiev 2012, Petrova 2014) and geochemistry of landscapes (Cholakova 2019, Tamburadzhiev and Cholakova 2020, Penin and Zhelev 2020). The modern landscape ecologists in Bulgaria follow the international landscape studies trends, mainly covering ecosystem services and land cover development (Grigorov et al. 2015, Nedkov 2018, Sarafova 2018, Assenov and Grigorov 2018; Gikov 2019, Nam and Tamburadzhiev 2019, Tamburadzhiev 2020), adoption of nature-based solutions, urban planning, pollution of waters and river valleys (Stoyanova et al.2020, Aydarova et al.2020). At the same time, only a few academics are publishing their studies internationally in prestigious academic journals (Nedkov and Burkhard 2012, Ihtimanski et al. 2020, Dodev et al. 2021). Thus, (i) limits the spread of the findings to a small national group of scientists, and (ii) reduce the development of more complex and internationally significant studies. This could be improved by conducting more experimental studies and integrating traditional multi-level landscape classifications and maps with modern studies such as ecosystem services assessment.

This study aims to propose an original methodology for mapping and assessing ecosystem services. To test the methods for a particular case study area and selected cultural ecosystem services and demonstrate that the multi-level landscape classification could be a valuable tool for ecosystem services studies.

\section{Materials and methods}

\subsection{Case study area (CSA)}

The study area is situated in North-Central Bulgaria, between Stara Planina Mountain to the south and the Danube Plain to the north. According to the geomorphological characteristic, the site is part of the so-called "inner" or "low" part of the Predbalkan region (Kanev 1989). Two main features included in the study area - Strazhata syncline upland to the south and Melovete hills to the north (Fig. 1).

In the $261 \mathrm{~km}^{2}$ study area, the widespread limestones cause karst topography, which predominant forms are high bare rocks, caves, sinkholes, karst fields, karst closed depressions and karst lake (Fig. 1). The site becomes significantly important because of the three rivers - Yantra, Dryanovska and Anduka, crossing the Strazhata upland and forming long narrow gorges. The highest point in the area is the Bozhurya peak $(768 \mathrm{~m})$, located in the Strazhata, and the lowest point is $135 \mathrm{~m}$ high.

Under the influence of karstification and because of the specific structure of the Strazhata and Melovete and wide distribution of limestone, many different underground and surface rock forms were
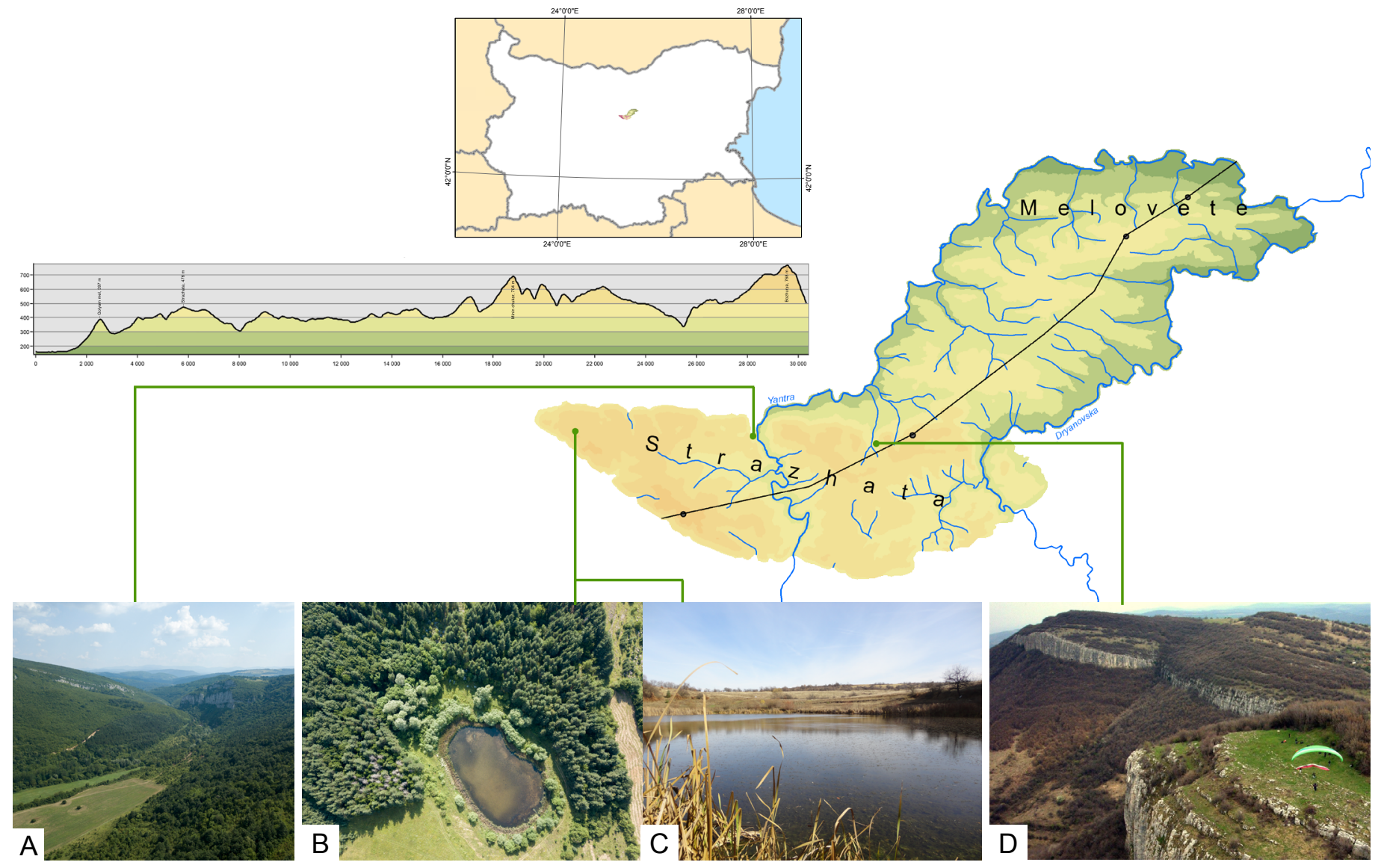

Figure 1. Location and characteristics of the CSA: A Yantra river gorge, B-C Bilyakovets Lake, D Minin Kamuk Karst Rocks. 
formed. The studied area falls into two karst regions - BelyakovskoArbanashki to the north and Strazhansko-Debeldyalski to the south (Popov 1976). As Angelova (2003) defines, the karst in the Strazhata is "the most typical of a syncline structure". Karst in the area is represented in various karst forms and karst fields, sinkholes, rock crowns, over 25 caves, karst springs and one lake - Bilyakovets Lake (Gerasimov 1984).

The climate in the region is temperate-continental with hot summers and cold winters, with maximum rainfall in summer and minimum in winter. The average annual temperature is about $11^{\circ} \mathrm{C}$, and the annual precipitation is about $680 \mathrm{~mm}$. The most common soils in the area are light grey (albic, LVa) and grey forest soils (haplic, LVh). There are also azonal alluvial-meadow soils (eutric, FLe), diluvial-meadow (gleyic, CLg) and humus-carbonate (rendzic, $\mathrm{LPk}$ ). According to the altitude division of the vegetation in Bulgaria (Assenov 2006) the CSA covers two of the natural vegetation zones - a belt of xerothermic oak forests (up to about $700 \mathrm{~m}$ ) and a belt of mesophilic oak and hornbeam forests (between 600-700 $\mathrm{m}$ to 900 $1000 \mathrm{~m})$.

Administratively, the region covers parts of the districts of Veliko Tarnovo (northeast) and Gabrovo (southwest). The area ratio between the lands of the two districts is 1:4 in favour of the Gabrovo region. The municipalities whose territories fall within the study area are Dryanovo (about $40 \%$ of the region), Gabrovo (30\%), Veliko Tarnovo (25\%) and Sevlievo (5\%). The number of settlements is over 70, 4 of them are urban - Veliko Tarnovo, Debelets, Dryanovo and Gabrovo. An important feature, which is also observed in other transitional and mountainous regions of the country, is that with increasing altitude from north to south, the number and density of settlements increase, and their size decreases.

\subsection{Spatial units. Landscape classification}

The most common landscape classifications schemes of Bulgaria are two. The first one followed the classification scheme of $\mathrm{N}$. Gvozdetsky and was used to compile a landscape map of Bulgaria at a scale of 1:400,000 (Petrov 1979). The second one (Beruchashvili et al. 1989) followed the classification scheme of Beruchashvili (1986, 1990) and was used to compile a landscape map of Bulgaria at a scale of 1:500,000 (Velchev et al. 1992)

As a basis for the landscape classification and map of the landscapes in the CSA, we used the landscape classification initially developed by Beruchashvili et al. (1989) and later refined by Velchev et al. (1992). Sharing Isachenko's views on the leading factor in the differentiation of individual levels and using additional criteria such as vegetation formations, the ratio between heat and humidity, the authors compile a landscape map of Bulgaria at a scale of 1:500 000 .

The most extensive taxonomic level in the study area is the landscape class (level 1). The leading factor for its characteristic is the relief and the most significant morphological structures. Given the transitional position of the Predbalkan region (between a mountain and a plain), we have classified two classes of landscapes Mountainous and Plain and hilly landscapes.

The second taxonomic level is the type of landscapes (level 2). The hydroclimatic conditions, identical for the different territories and influencing the distribution of the vegetation, are the primary factor in its differentiation. According to the various combinations between the climatic features, temperature and humidity, the general features of the structure, and the hydrological conditions, Velchev et al. (1992) classified types of landscapes, such as hilly subtropical humid, flat, and flat hilly Mediterranean semi-humid, etc. According to these criteria, three landscape types have been identified in the CSA, two zonal - Mountain type moderate warm semi-humid landscapes and Plain and hilly moderate warm humid, and one azonal type - Hydromorphous and sub-hydromorphous landscapes.

The third taxonomic level is occupied by the genus of landscapes (level 3). The main factor in its separation is the type of predominant relief related to the chemical features of the underlying rock base and the ongoing geomorphological processes. According to the criteria, seven types of landscapes have been separated - two within the Mountain type moderate warm semi-humid landscapes, four within the Plain and hilly moderate warm, humid landscapes, and one within the Hydromorphous and sub-hydromorphous landscapes.

The fourth level includes the units of landscapes, and the main factor is the soil diversity within the area. We classified fifteen units within the previous level of the classification.

According to anthropogenic interventions, the fifth level is the sub-units of landscapes, reflecting the primary vegetation. CORINE Land Cover classes are taken into account to separate the boundaries of the sub-unit landscapes.

As a result of the analysis of the landscape-forming factors, the comparison of thematic maps on different scales for the components that make up the landscape and refining their content in the field, we developed a map of the contemporary landscapes of Strazhata and Melovete at a scale of 1:50 000. We used several thematic maps as a basis: a geological map at a scale of 1:100 000; a topographic map at a scale of 1:50 000; soil maps from the Institute of soil science, agrotechnologies and plant protection "Nikola Poushkarov" at a scale of 1:25 000; a map of the natural vegetation of Bulgaria at a scale of 1:600 000 (Bondev 1991), CORINE Land Cover (CLC 2018) and satellite images from the European Space Agency. All thematic maps were scanned and georeferenced. Based on them, we created new vector layers, which we further used to represent the individual levels of the classification system. The landscape map has been developed in a specialized GIS program - ArcGIS, version 10.1. Some of its components have been edited using a professional commercial program for raster image processing - Adobe Photoshop, version CS6. The map at a scale of 1:50 000 presents 41 landscape differences through alphanumeric designations according to the applied classification system systematized in 2 classes, 3 types, 3 subtypes, 7 genera, 15 units and 41 sub-units of landscapes (Fig. 2).

\subsection{Ecosystem services}

The cultural ecosystem services assessed in this study have been previously prioritised by Nedkov et al. (2021). Fifteen services were defined as high priority services. These services are obligatory for each mapping and assessment activity of the natural heritage of Bulgaria for the needs of recreation and tourism and serve as reference services for mapping at a national level. The first one is "IX Conditions for recreation by biotic systems", including 1. Provision of recreation environment; 2. Provision of sports environment; 3 . Provision of the environment; 4. Conditions for cognitive activity, all of them shortly named as "recreation". The second one is "XIV Conditions for recreation by abiotic systems", including 1 . Provision of recreation environment; 2. Provision of sports environment; 3. Provision of the environment; 4 . Conditions for cognitive activity, shortly named as "eco-tourism". The sports activities we are identifying with this service include hiking, climbing and paragliding.

\subsection{Assessment procedure}

The assessment of the landscapes to provide ES has been achieved through the matrix approach, developed by Burkhard et al. (2009). As spatial units for the matrix assessment, we used 41 contemporary landscapes in the area (Table 1 and Fig 2), classified and mapped by Prodanova (2018). The classification of the modern landscapes contains five levels, divided per the previously selected factors for landscape diversity: 
Table 1. Landscape classification and assessment matrix.

\begin{tabular}{|c|c|c|c|c|c|c|c|c|}
\hline Level 1 & $\begin{array}{l}\text { L A N D S C A } \\
\text { Level } 2\end{array}$ & $\begin{array}{l}E \underset{\text { Level } 3}{C} \text { L A S S I F I C } \\
\text { l }\end{array}$ & $\begin{array}{l}\text { A T I O N } \\
\text { Level } 4\end{array}$ & A S S E S S & $\begin{array}{l}\text { M E N T } \\
\text { Area }\left(\mathrm{km}^{2}\right)\end{array}$ & $\begin{array}{l}\text { R E S U L } \\
\text { Cult. ES } \Sigma\end{array}$ & $\begin{array}{l}\mathrm{L} T \\
\operatorname{Rec}\end{array}$ & $\begin{array}{l}S \\
\text { Eco }\end{array}$ \\
\hline \multirow{15}{*}{$\begin{array}{l}\text { Mountain } \\
\text { landscapes }\end{array}$} & \multirow{15}{*}{$\begin{array}{l}\text { Moderate warm } \\
\text { Semihumid }\end{array}$} & \multirow[t]{5}{*}{ Karst ridges over limestones } & \multirow[t]{2}{*}{ Leptosols Rendzik } & 1a Mixed broadleaf forests & 0,39 & 10 & 5 & 5 \\
\hline & & & & 1b Agricultural & 0,19 & 6 & 2 & 4 \\
\hline & & & \multirow[t]{3}{*}{ Luvisols Albic } & 2a Mixed broadleaf forests & 6,01 & 10 & 5 & 5 \\
\hline & & & & $2 \mathrm{~b}$ Agricultural & 6,47 & 6 & 2 & 4 \\
\hline & & & & 2c Meadows & 5,67 & 9 & 4 & 5 \\
\hline & & \multirow{10}{*}{$\begin{array}{l}\text { Karst erosion-denudation } \\
\text { hillsides over limestones }\end{array}$} & \multirow[t]{4}{*}{ Leptosols Rendzik } & 3a Mixed broadleaf forests & 2,92 & 10 & 5 & 5 \\
\hline & & & & 3b Agricultural & 0,15 & 5 & 1 & 4 \\
\hline & & & & 3c Meadows & 0,79 & 9 & 4 & 5 \\
\hline & & & & 3d Artificial coniferous forests & 0,58 & 8 & 4 & 4 \\
\hline & & & \multirow[t]{5}{*}{ Luvisols Albic } & 4a Mixed broadleaf forests & 40,72 & 10 & 5 & 5 \\
\hline & & & & 4b Agricultural & 27,40 & 6 & 2 & 4 \\
\hline & & & & 4c Meadows & 9,96 & 9 & 4 & 5 \\
\hline & & & & $4 \mathrm{~d}$ Artificial coniferous forests & 0,96 & 8 & 5 & 3 \\
\hline & & & & 4e Orchard and vineyards & 1,65 & 7 & 2 & 5 \\
\hline & & & Colluvisols Gleyik & 5c Meadows & 0,96 & 10 & 5 & 5 \\
\hline \multirow{26}{*}{$\begin{array}{l}\text { Plain and hills } \\
\text { landscapes }\end{array}$} & \multirow[t]{24}{*}{ Moderate warm Humid } & \multirow[t]{3}{*}{ Karst ridges over limestones } & Leptosols Rendzik & 6c Meadows & 0,61 & 9 & 5 & 4 \\
\hline & & & & $6 f$ Mixed oak forests & 1,01 & 9 & 5 & 5 \\
\hline & & & Luvisols Haplik & $7 f$ Mixed oak forests & 0,18 & 10 & 5 & 5 \\
\hline & & \multirow{9}{*}{$\begin{array}{l}\text { Karst erosion-denudation } \\
\text { hillsides over limestones }\end{array}$} & \multirow[t]{3}{*}{ Leptosols Rendzik } & 8b Agricultural & 0,89 & 5 & 2 & 3 \\
\hline & & & & $8 \mathrm{e}$ Orchard and vineyards & 0,10 & 7 & 2 & 5 \\
\hline & & & & $8 f$ Mixed oak forests & 2,64 & 10 & 5 & 5 \\
\hline & & & \multirow[t]{4}{*}{ Luvisols Albic } & 9b Agricultural & 5,96 & 5 & 2 & 3 \\
\hline & & & & 9c Meadows & 1,41 & 9 & 5 & 4 \\
\hline & & & & 9e Orchard and vineyards & 0,19 & 7 & 2 & 5 \\
\hline & & & & 9f Mixed oak forests & 1,34 & 10 & 5 & 5 \\
\hline & & & \multirow[t]{2}{*}{ Luvisols Haplik } & 10b Agricultural & 0,41 & 9 & 4 & 5 \\
\hline & & & & 10e Mixed oak forests & 0,21 & 9 & 4 & 5 \\
\hline & & \multirow{5}{*}{$\begin{array}{l}\text { Denudation-erosion ridges } \\
\text { over sandstones and marls }\end{array}$} & \multirow[t]{4}{*}{ Luvisols Haplik } & 11b Agricultural & 7,26 & 3 & 1 & 2 \\
\hline & & & & 11c Meadows & 2,54 & 7 & 4 & 3 \\
\hline & & & & 11e Orchard and vineyards & 0,12 & 6 & 1 & 5 \\
\hline & & & & $11 \mathrm{f}$ Mixed oak forests & 3,29 & 7 & 3 & 4 \\
\hline & & & Leptosols Rendzik & 12c Meadows & 0,58 & 8 & 4 & 4 \\
\hline & & \multirow{7}{*}{$\begin{array}{l}\text { Erosion-denudation hillsides } \\
\text { over sandstones and marls }\end{array}$} & \multirow[t]{3}{*}{ Leptosols Rendzik } & 13b Agricultural & 2,89 & 3 & 1 & 2 \\
\hline & & & & 13c Meadows & 0,68 & 7 & 4 & 3 \\
\hline & & & & 13f Mixed oak forests & 1,04 & 7 & 3 & 4 \\
\hline & & & \multirow[t]{4}{*}{ Luvisols Haplik } & 14b Agricultural & 38,62 & 3 & 1 & 3 \\
\hline & & & & 14c Meadows & 9,23 & 7 & 4 & 3 \\
\hline & & & & $14 \mathrm{e}$ Orchard and vineyards & 2,13 & 5 & 1 & 4 \\
\hline & & & & $14 \mathrm{f}$ Mixed oak forests & 36,95 & 7 & 3 & 4 \\
\hline & \multirow{2}{*}{$\begin{array}{l}\text { Hydromorphous and } \\
\text { subhydromorphous }\end{array}$} & \multirow{2}{*}{$\begin{array}{l}\text { Acumulative lowlands and } \\
\text { valleys }\end{array}$} & \multirow[t]{2}{*}{ Fluvisols Eutric } & 15b Agricultural & 7,05 & 4 & 1 & 3 \\
\hline & & & & $15 \mathrm{~g}$ Riverside forests & 8,50 & 9 & 4 & 5 \\
\hline & & & & Urb Urban landscapes & 20,97 & 0 & 0 & 0 \\
\hline
\end{tabular}

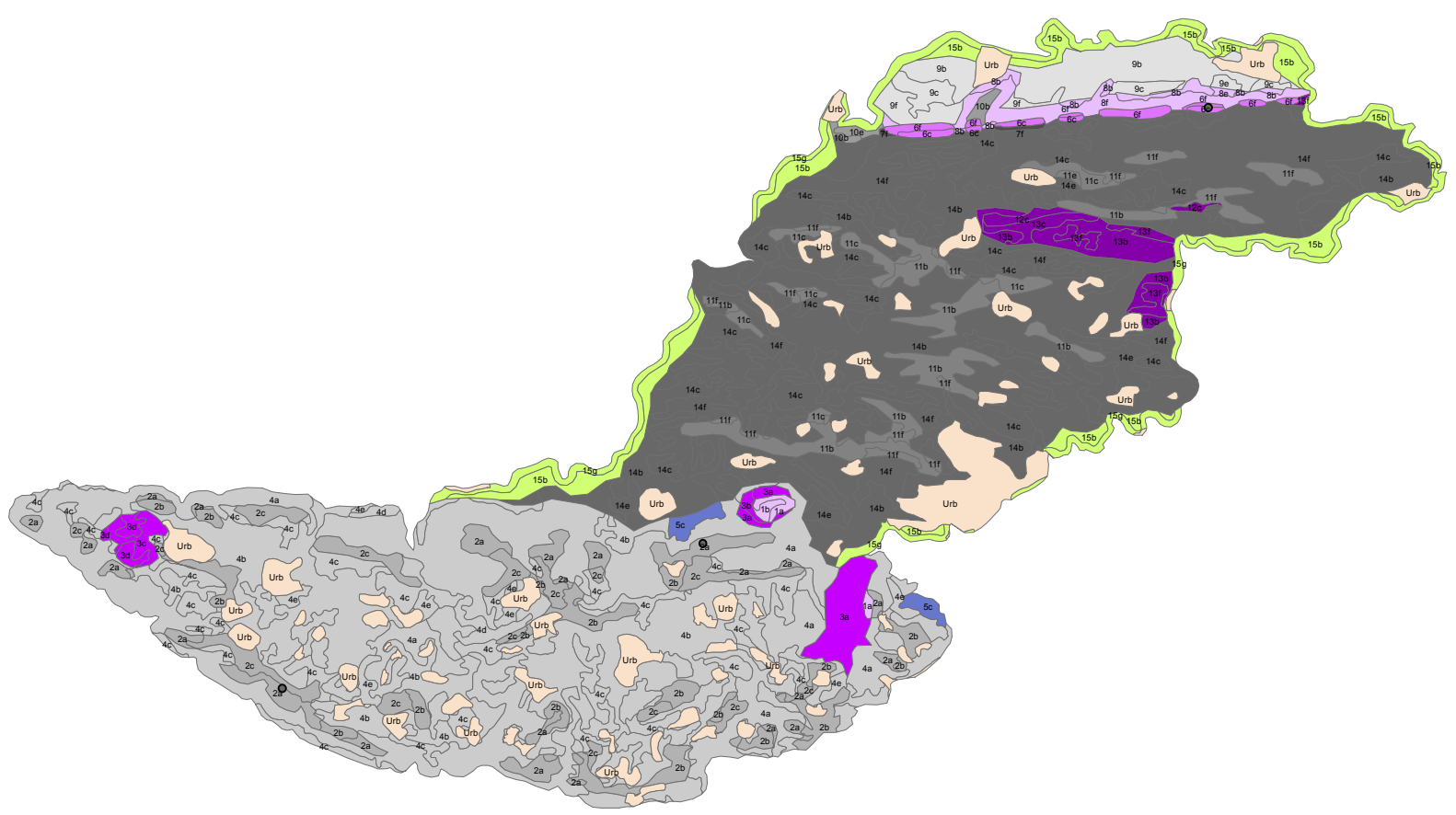

Figure 2. Contemporary landscapes of Strazhata upland and Melovete hills. 
- Level 1 - Class landscapes (main relief type);

- Level 2 - Type landscapes (climate conditions);

- Level 3 - Genus landscapes (relief forms and base rocks);

- Level 4 - Units (soils);

- Level 5 - Sub-units (land cover).

The 41 contemporary landscapes have been rated by an expert assessment on a scale of 0 to 5 for both cultural ecosystem services recreation and ecotourism, where zero means "no relevant capacity" and five means "very high relevant capacity". We carried out two assessment maps, showing the capacity of the landscapes to provide recreation and ecotourism services.

Regarding critical specifics of the cultural ES recreation and ecotourism, we used the following seven criteria in the assessment process:

- Landscapes characteristics according to the multi-level classification;

- Distribution of the settlements, road or forest ways and easiness to reach the area;

- Forest distribution and species diversity;

- Existing relief forms, suitable for practising different sports activities;

- Existing protected areas (at EU and national level);

- Existing proper places for observations and site viewing;

- Existing touristic trails.

\section{Results}

The scores in the matrix (Table 1) were given by experts, asked to estimate the potential of the landscapes to provide ecosystem services. The highest scores were given to Karst landscapes with broad-leaved and oak forest sub-units of landscapes, which gained the maximum sum score of 10 . The agricultural landscapes within plains and hills had the lowest potential, with a sum score of 3 . The urban areas with dumpsites are estimated to have no potential for both ES with a sum score of 0 .
The scores from the matrix were used to generate ES maps at a local level (Fig. 4-5). The areas of the very high potential of the landscapes were located mainly in the mountain, plateau and hilly karst areas of the Strazhata upland and Melovete hills and in some floodplain with riparian vegetation where forest ecosystems are the predominant type.

Most of the CSA territory exhibits medium potential. At the same time, nearly $30 \%$ of the territory gained the highest score for the potential of the landscapes to provide recreation and ecotourism (Fig 6-7). Around $90 \%$ of the cases, the landscapes with the highest scores fall into NATURA 2000 sites (i.e. "Vitata stena" and "Skalsko" within the Strazhata upland) or other natural monuments and protected areas. Exception from this rule were the karst areas of Melovete hills, which are not included in any protected site.

Comparison between scores for both ES (Fig. 7) showed that the landscapes have a higher capacity to provide ecotourism - more than $60 \%$ of the territory scored with very high (5) and high potential (4). Vice versa, only $37 \%$ of the territory has very high and high capacity to provide the ecosystem service "recreation".

\section{Discussion}

The results show that more than $70 \%$ of the area has a medium relevant or higher capacity to provide such services. With the specific karst relief, we explain that forests and rivers give high value to the landscapes and can provide different cultural services related to various outdoor activities such as hiking, climbing, paragliding, site watching, and observing protected species. Five NATURA 2000 sites and five protected sites at a national level are protecting biodiversity in the area. More than $80 \%$ of the protected territories are located in the Strazhata syncline upland. They preserve the karst landscapes, including more than 20 caves with ten bat species habitats.

We assume that the proposed experimental approach for mapping and assessing ecosystem services based on multi-level landscape classification gives a new vision of traditional landscape
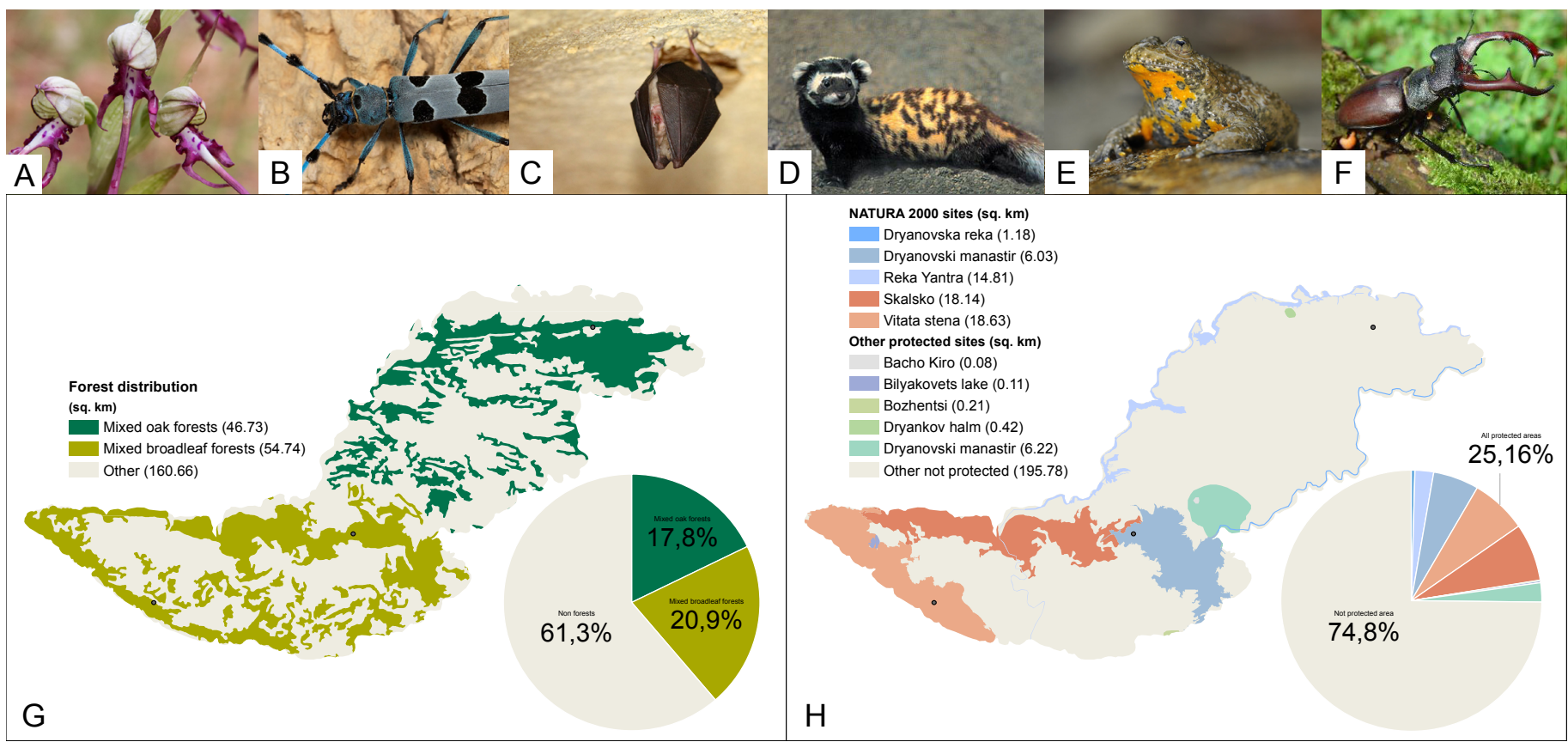

Figure 3. Distribution of the indicators: A-F Species diversity, (Himantoglossum caprinum (M.Bieb.) Spreng; Rosalia alpina L.; Hipposideros hipposideros Bechstein; Vormela peregusna Güldenstädt; Bombina variegata L.; Lucanus cervus L.) G Forest distribution, H Existing protected areas. Picture sources are listed in the end of the paper. 


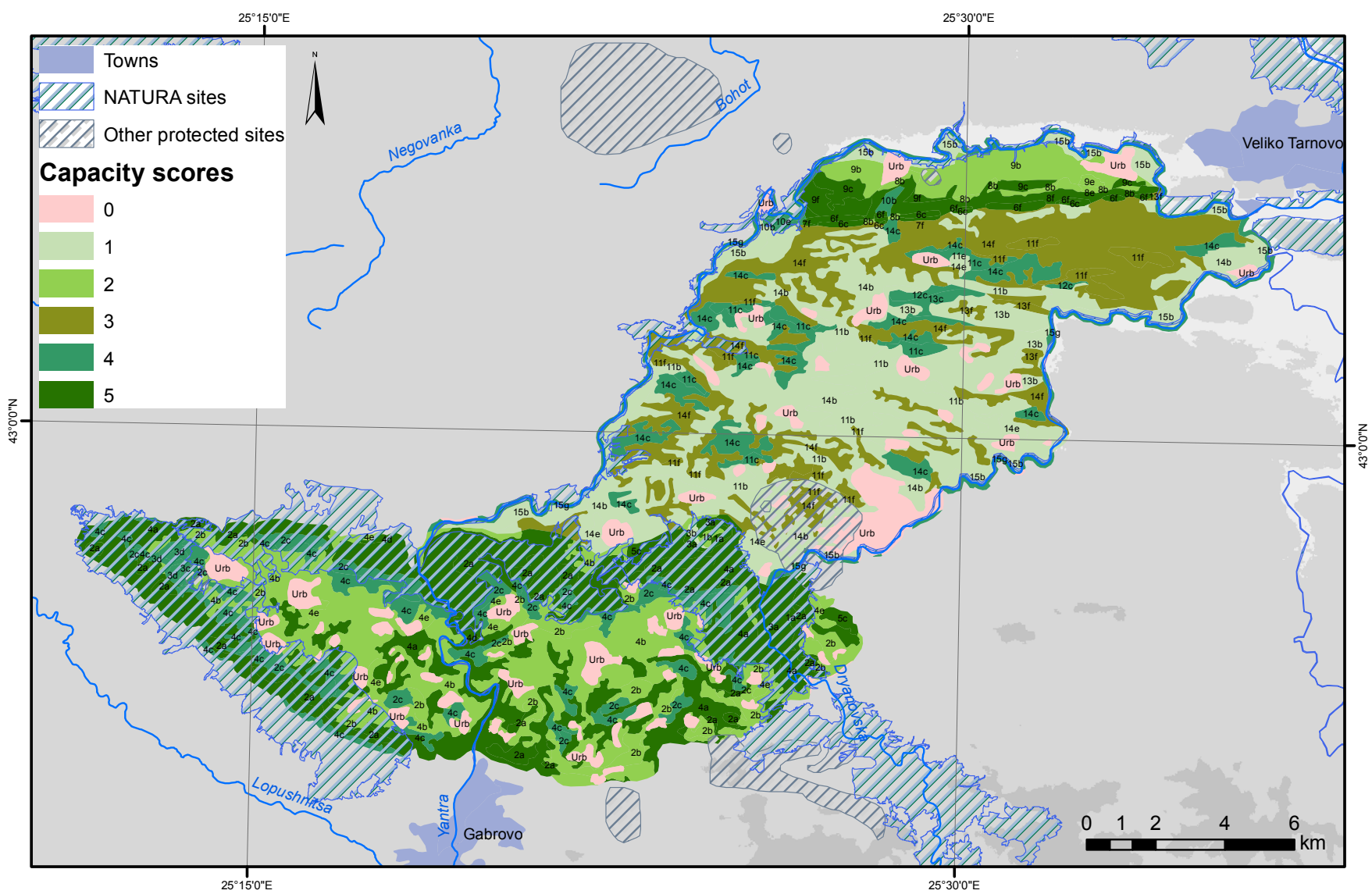

Figure 4. Capacity of the landscapes of Strazhata and Melovete to provide the cultural ES Recreation.

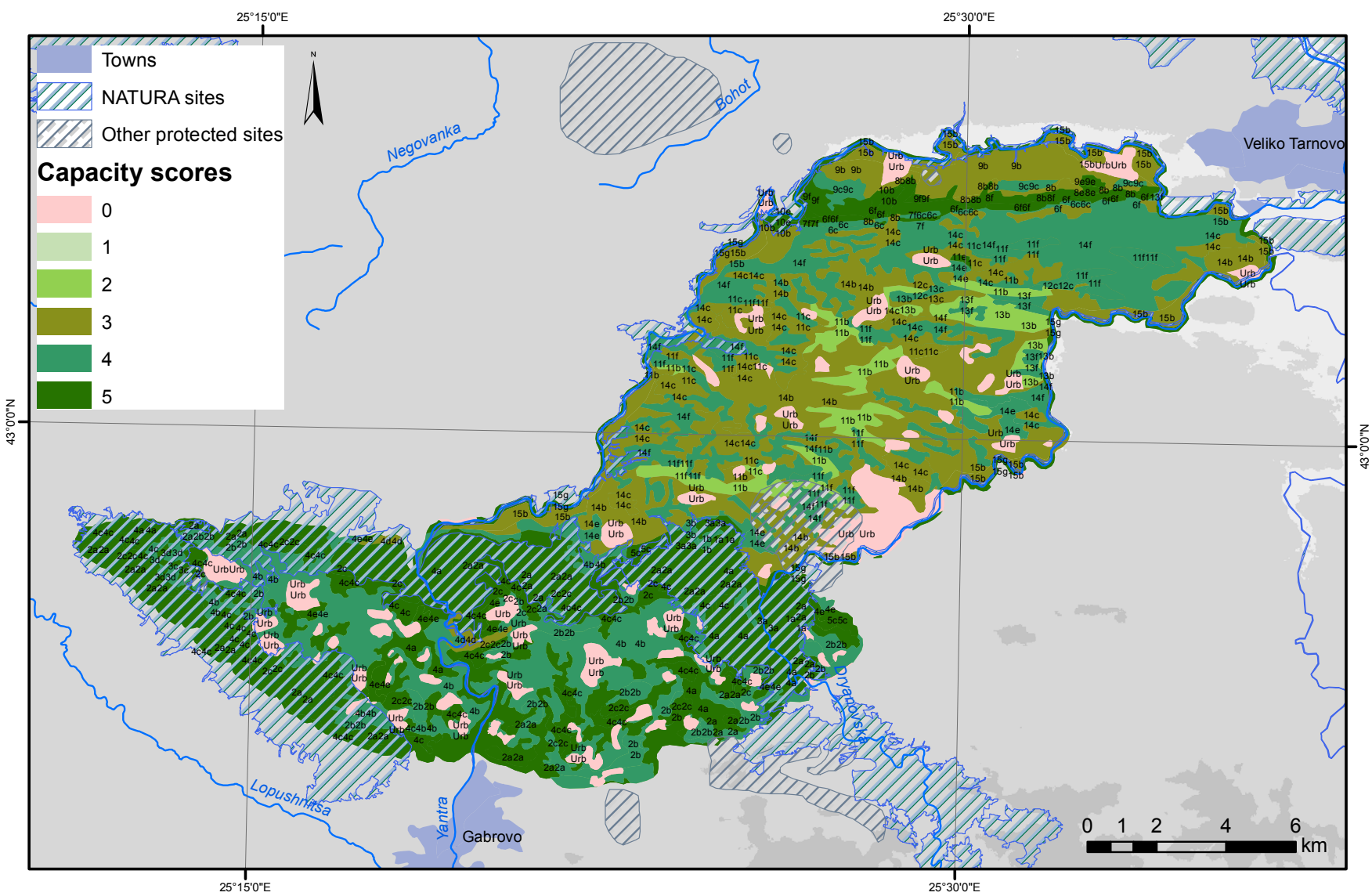

Figure 5. Capacity of the landscapes of Strazhata and Melovete to provide the cultural ES Ecotourism. 


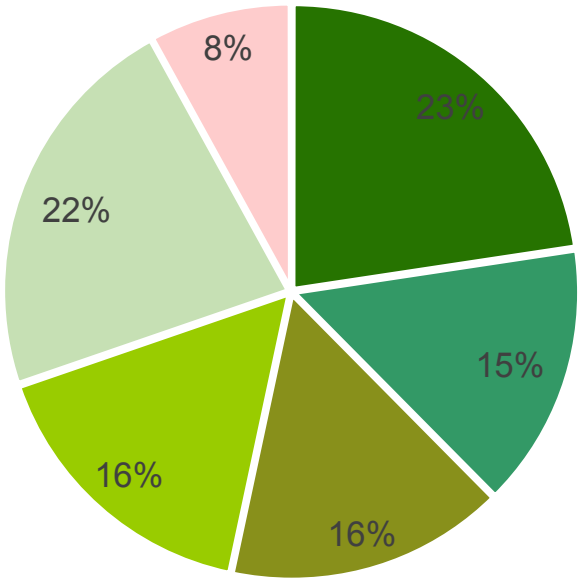

Recreation

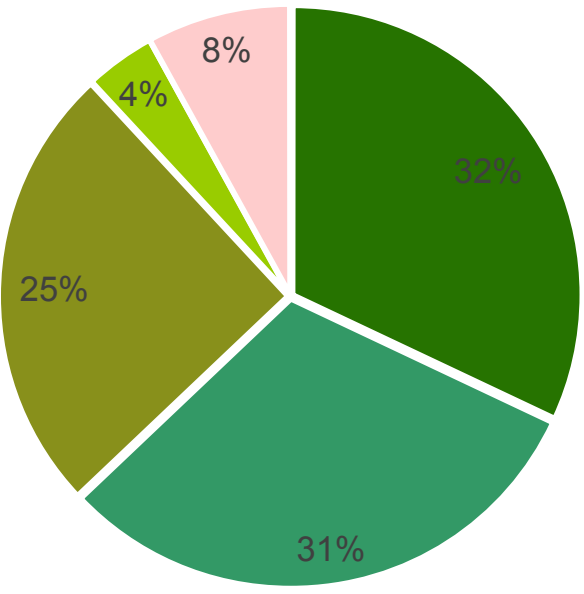

Ecotourism

Figure 6. Capacity of the landscapes to provide cultural ecosystem services (\% of the CSA).

A

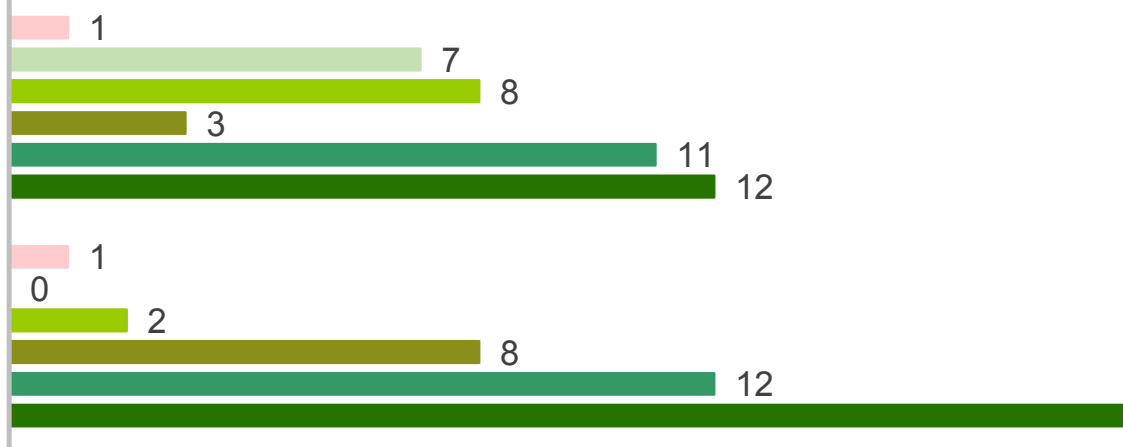

Figure 7. Comparison between capacity of the landscapes to provide A Recreation and B Ecotourism ( $\mathrm{n}$ - number of sub-unit landscapes).

ecological methods. The multi-level landscape classifications are valuable information regarding a specific territory, integrating thematic layers for rocks, soils, vegetation, and anthropogenic changes. Their integration with the ecosystem services concepts and methods will increase the number of landscape studies in Bulgaria. As a result, more detailed approaches have to be developed and tested at different scales. The findings should be published in international journals to reach a broader range of scientists for discussion and further research activities.

\section{Conclusion}

We found that specific karst relief combined with other indicators in the Strazhata and Melovete provide the highest capacity for recreation and ecotourism ecosystem services contrary to the middle part of the research area, where karst relief is not presented, and it's not protected. Furthermore, low human pressure on the environment in the last 20 years, due to the villages' depopulation and abandoning the agricultural lands, is the reason for self-restoration of the landscapes and transition to a more natural environment. Several protected areas cover $24.8 \%$ of the site, and most of them are located in the karst territory of Strazhata syncline upland.

\section{Funding program}

This research was funded by the BG05M2OP001-1.001-0001 Project "Creation and development of "Heritage BG" Centre of Excellence", Operational Programme Science and Education for Smart Growth, Priority axis 1, Procedure BG05M2OP001-1.001, Component 4 "New technologies in creative and recreation industries". This work was also supported by the Bulgarian Ministry of Education and Science under the National Research Programme "Young scientists and postdoctoral students" approved by DCM No 577/17.08.2018.

\section{Acknowledgments}

The author would like to thank Daniel and Nikoleta Tilkovi for the technical assistance during field observations, Gergana Zhivkova for the technical support upon formatting the manuscript, and to Yana Georgieva for copyediting.

\section{References}

Angelova D (2003) Karst types in Bulgaria. Acta carsologica, 32(1): 9-18. https:// digital.lib.usf.edu/content/SF/S0/05/05/96/00001/K26-00147-angelova.pdf Assenov A, Grigorov B (2018) Development of the land cover in Mala Planina. Journal of the Bulgarian Geographical Society 39: 79-82. http:// geography.bg/publication/magazines/item/370-vol39-2018-15 
Aydarova Z, Kotsev T, Tchorbadjieff A, Tcherkezova E, Stoyanova V (2020) Grouping of groundwater monitoring points in river floodplain according to the conditions for arsenic contamination. Problems of Geography 1-2(2021): 79-100. https://doi.org/10.35101/prg-2020.1-2.6

Batakliev I (1934) Landscape division of Bulgaria. Annual of Sofia University, Faculty of History and Philology 30(13): 3-43. (in Bulgarian)

Berg LS (1913) Opyt razdeleniya Sibiri i Turkestana na landshaftnye i morfologicheskie oblasti [An attempt at the division of Siberia and Turkestan into landscape and morphological regions]. In: Sbornik v chest' 70-letiya D N Anuchina [Festchrift in honor of D. N. Anuchin's seventieth birthday]: 117-51. Moscow: Izdatel'stvo Imperatorskogo obshchestva Lyubitelei Estestvoznaniya, Antropologii i Etnografii pri Moskovskom universiteta (in Russian)

Beruchashvili N (1986) Four Dimensions of Landscape. Moscow, Misl. (in Russian)

Beruchashvili N (1990) Landscape Geophysics. Moscow, Viyshaya shkola. (in Russian)

Bondev I (1991) The vegetation of Bulgaria. Map at a scale of 1:600 000 with explanatory text. "St. Kliment Ohridski” University Press, Sofia. (in Bulgarian)

Burkhard B, Kroll F, Müller F, Windhorst W (2009) Landscapes' Capacities to Provide Ecosystem Services - a Concept for Land-Cover Based Assessments. Landscape Online 15: 1-22. https://doi.org/10.3097/ L0.200915

Cholakova Z (2019) Comparative analysis of the content of heavy metals in the soils of karst landscapes. Journal of the Bulgarian Geographical Society 40:2429. http://geography.bg/publication/magazines/item/416-vol40-2019-4

Dokuchaev VV (1949) "K izucheniyu o zonakh prirody [Toward the study of the zones of nature]". In: Izbrannye sochineniya [Selected essays], Vol. 3: 317-22. Moscow: Gosudarstvennoe izdatel'stvo Sel'skokhozyaistvennoi Literatury. (Orig. pub. 1898-1899 in Russian)

Dodev Y, Zhiyanski M, Glushkova M, Borisova B, Semerdzhieva L, Ihtimanski I, Dimitrov S, Nedkov S, Nikolova M, Shin WS (2021) An Integrated Approach to Assess the Potential of Forest Areas for Therapy Services. Land 2021, 10, 1354. https://doi.org/10.3390/land10121354

Finke L (1996) Landschaftsökologie. Das Geographische Seminar, Braunschweig, $245 \mathrm{~S}$.

Gerasimov I (1984) Grand Caucase-Stara Planina (le Balkan): analyse géographique comparée du potentiel des ressources naturelles et son rôle dans le développement et la localisation de l'économie et la population des pays montagneux. Editions de l'academie bulgare des sciences, 434 pp. (in French)

Gikov A (2019) Large-scale mapping and analysis of changes in contemporary landscapes over a 50-year period in the key area "Bogdaia", northwestern Rila Mountains. Journal of the Bulgarian Geographical Society 41: 23-30. http://geography.bg/publication/magazines/ item/373-vol41-2019-4 (in Bulgarian)

Grigorov B, Dimitrov P, Assenov A (2015) Landscape biodiversity of Mala Planina Mountain. Problems of Geography 1-2: 154-165. http://geoproblems. eu/wp-content/uploads/2015/12/2015_12/16_grigorov_2015_12.pdf

Haase $\mathrm{G}$ et al. (1991) Naturraumerkundung und Landnutzung - Geochorologische Verfahren zur Analyse, Kartierung und Bewertung von Naturräumen. Beitr. z. Geogr., Bd.34/1 u. 34/2, Berlin, 373 S. + Beilagenband. (in German)

Haase G, Mannsfeld K (Eds) (2002) Naturraumeinheiten, Landschaftsfunktionen und Leitbilder am Beispiel von Sachsen. Forschg. z. dt. Landeskde., Bd.250, Flensburg, 214 S. (in German)

Huggett R, Perkins C (2004) Landscape as form, process and meaning. In John A. Matthews, David T. Herbert (Eds), Unifying Geography: Common Heritage, Shared Future. Routledge: 224-39.

Isachenko AG (1961) The landscape maps of the USSR at 1:4,000,000 and some aspects of the methodology of landscape study. In: Materialy $\mathrm{k}$ V Vsesoyuzn. soveshch. po voprosam landshaftvedeniya (Proceedings of the Fifth All-Union Conference on Landscape Science), Moscow. (in
Russian)

Isachenko AG (1962a) Brief methodological instruction for compilation of the landscape map of the USSR at 1:4,000,000. Izv. VGO, 1962, No. 5. (in Russian)

Isachenko AG (1962b) Examples of showing landscapes of the USSR on the 1:4,000,000 map. In: Materialy Komissii po landsh. kartam Geogr. obsh. SSSR (Proceedings of the Commission on Landscape Maps of the Geographical Society USSR), No. 2, 1962. [Google Scholar]

Isachenko AG (1963) Problems of showing mountain landscapes on smallscale landscape maps. In: Landshaftovedeniye (Landscape Science), Moscow: Academy of Sciences USSR. (in Russian)

Kanev D (1989) Geomorphology of Bulgaria. Sofia. 322 p. (in Bulgarian)

Konteva M, Penin R, Cholakova Z, Momerova B (2008) Assessment of contemporary structure and geoecological status of the landscape in Gaber cettle (Burel). In: Proceedings of the Fifth International Conference "Global Changes: "Vulnerability, Mitigation and Adaptation”, 17-18 April 2008, Sofia, Bulgaria, Uni. Press, 103-108. (in Bulgarian)

Nam K, Tamburadzhiev I (2019) Specificity of the anthropogenic landscapes in part of the catchment area of Luda Yana River. Journal of the Bulgarian Geographical Society 41: 31-36. http://geography.bg/publication/ magazines/item/427-vol41-2019-5

Neef E (1967) Die theoretischen Grundlagen der Landschaftslehre. Gotha, 152 S.

Neef E, Schmidt G, Lauckner M (1961) Landschaftsökologische Untersuchungen an verschiedenen Physiotopen in Nordwestsachsen. Abh. d. Sächs. Akad. d. Wiss. zu Leipzig, Math.-nat. Kl., Bd.47, H.1, Berlin, 112 S.

Nedkov S, Burkhard B (2012) Flood regulating ecosystem services - Mapping supply and demand, in the Etropole municipality, Bulgaria. Ecological Indicators 21: 67-79. https://doi.org/10.1016/j.ecolind.2011.06.022

Nedkov S (2018) GIS tools and models for mapping and assessment of ecosystem services. Journal of the Bulgarian Geographical Society 39: 17-24. http://geography.bg/publication/magazines/item/397-vol39-2018-3 (in Bulgarian)

Nedkov S, Nikolova M, Mitova R, Borisova B, Hristova D, Semerdzhieva L, Zhiyanski M, Prodanova H (2021) Prioritization of ecosystem services related to the natural heritage of Bulgaria. Journal of the Bulgarian Geographical Society 45: 19-30. https://doi.org/10.3897/jbgs.e73687

Nikolova M, Stoyanova V, Varadzhakova D, Ravnachka A (2021) Cultural ecosystem services for development of nature-based tourism in Bulgaria. Journal of the Bulgarian Geographical Society 45: 81-87. https://doi.org/10.3897/jbgs.e78719

Passarge S (1921) Die Grundlagen der Landschaftskunde, Vols. 1-2, Hamburg, L. Friederichsen \& Co.

Penin R, Zhelev D (2020) Pre-Monitoring Biogeochemical Research of the landscapes in the Area of Ada Tepe Gold Mining Site (Eastern Rhodopes). Journal of the Bulgarian Geographical Society 43: 25-30. http://geography.bg/publication/magazines/item/475-vol43-2020-4

Petrova M (2014) The spatial structure of the landscapes as an indicator of their anthropogenisation. In: Proceedings of the scientific conference "30 years Department of Geography in "St. Cyril and St. Methodius" University of Veliko Tarnovo": 42-46. (in Bulgarian)

Petrova M (2020) The synergetic approach in the landscape studies. Journal of the Bulgarian Geographical Society 43: 79-85. http://geography.bg/ publication/magazines/item/484-vol43-2020-13 (in Bulgarian)

Popov V (1976) Caves regionalization of Bulgaria. Problems of Geography 2(2): 14-24. (in Bulgarian)

Potschin M (1996) Nährstoff- und Wasserhaushalt im Kvikkåa-Einzugsgebiet, Liefdefjorden (NW-Spitzbergen) - das Landschaftsökologische Konzept in einem hocharktischen Geoökosystem. Physiogeographica, Bd.23, Basel, 258 S. + Anhang. (in German)

Prodanova H (2018) Opportunities for Forestry Development of the Landscapes of Strazhata and Melovete in Central Predbalkan Region. Annual of Sofia University "St. Kliment Ohridski”, Faculty of Geology and Geography, 
Book 2 - Geography, Volume 110: 163-179. https://www.uni-sofia.bg/ index.php/bul/universitet_t/fakulteti/geologo_geografski_fakultet/ oficialni_izdaniya/kniga_2_geografiya_tom_110(in Bulgarian)

Richter H (1961) Beitrage zum Modell des Geokomplexes. In: Neef, E Festschrift - Landschaftsforchung. PDM Erg. H.271: 63-79. (in German)

Richter H (1967) Naturräumliche Ordnung. In: Wiss. Abh., Geogr. Ges. DDR, 5: 129-160.

Sarafova E (2018) Spatial Modeling of the Ecotourism Potential of Kyustendil Municipality through Analytic Hierarchy Process and Remote Sensing Data in GIS. Journal of the Bulgarian Geographical Society 39: 45-50. http://geography.bg/publication/magazines/item/402-vol39-2018-8 (in Bulgarian)

Solntsev N (1948) The doctrine of landscape morphology, Textbook, Moscow, 123 pp.

Stoyanova V (2016) Classification of landscapes in Bulgaria (Overview). In: Proceedings of the Fifth International Conference "Geographical Sciences and Education", University of Shumen "Bishop Konstantin Preslavski”, ISBN 978-619-201-172-7, pp 154-158. (in Bulgarian)

Stoyanova V, Kotsev T, Tcherkezova E (2020) Hazard of heavy metal pollution of soil by flooding from Danube in the Tsibarska lowland. Comptes rendus de l'Acad emie bulgare des Sciences, Tome 73, No 8, 2020: 1102-1107. http://dx.doi.org/10.7546/CRABS.2020.08.08

Tamburadzhiev I, Cholakova Z (2020) Structure and Peculiarities of the Karst Landscapes in the Besaparski Ridges. In: Nedkov S. et al. (eds) Smart Geography. Key Challenges in Geography (EUROGEO Book Series).Springer, Cham:289-302.https://doi.org/10.1007/978-3-030-28191-5_23

Tamburadzhiev I (2020) Analysis of the anthropogenization of the landscapes in the area of Plovdiv agglomeration. In: Proceedings of "International seminar of ecology - 2019" Dedicated to the 75th anniversary of USB and the 150th anniversary of BAS: 55-65.

Todorov N, Alexiev T (2012) Specificity of landscapes in the vicinity of Belogradchik.Problems of Geography 1-2: 117-132.http://geoproblems. eu/wp-content/uploads/2016/02/2012_12/10_todorov.pdf

Tzvetkov J (2017) A web-map of the landscapes of Vitosha Mountain and the development of landscape science in Bulgaria. Forum geografic. Studii și cercetări de geografie și protecția mediului, Volume XVI, Issue 2 (December 2017): 126-131. http://dx.doi.org/10.5775/fg.2017.023.d

Tzvetkov J (2021) Development and state of the art of landscape science in Bulgaria. Acta Universitatis Carolinae. Geographica. Univerzita Karlova 56(2): 195-204.https://doi.org/10.14712/23361980.2021.13

Velchev A, Todorov N, Assenov A, Beruchashvili N (1992) A landscape map of Bulgarian at a scale of 1:500 000. Annual of Sofia University "St. Kliment Ohridski”, Faculty of Geology and Geography, Book 2 - Geography, Volume 84: 85-107. (in Bulgarian)

Zhelezov G, Nedkov S (2019) Development of the landscape researches in Bulgaria. Problems of Geography 2: 71-85. https://geoproblems.eu/ en/2019-vol-2/\#6 (in Bulgarian)

CLC (2018) https://land.copernicus.eu/pan-european/corine-land-cover/clc2018 https://paratandem.com/home/ - Fig. 1D

https://www.naturephoto-cz.com/rosalia-alpina-photo_lat-3301.html - Fig. 3B https://en.wikipedia.org/wiki/File:Marbled_polecat.jpg - Fig.3D https://www.vr-balkan.net/bg/zemnovodni-i-vlechugi/ - Fig. 3E

\section{ORCID}

https://orcid.org/0000-0003-2453-8975 - H. Prodanova 